\title{
Élelmiszer-biztonsági jelentőségü baktériumok molekuláris detektálásának fejlesztése miniatürizált mikrofluidikai eszközök segítségével
}

\author{
Iván Kristóf dr. ${ }^{1^{*}}$ - Maráz Anna dr. ${ }^{2^{*}}$ \\ ${ }^{1}$ Pázmány Péter Katolikus Egyetem, Információs Technológiai és Bionikai Kar, Budapest \\ ${ }^{2}$ Budapesti Corvinus Egyetem, Élelmiszertudományi Kar, Mikrobiológia és Biotechnológia Tanszék, Budapest
}

\begin{abstract}
A biztonságos élelmiszerek elóállítása szempontjából kulcsfontosságú az élelmiszerrel terjedő patogén baktériumok kimutatása és azonosítása. A hagyományos, tenyésztésen alapuló diagnosztikai eljárásokat egyre inkább felváltják vagy kiegészítik a nukleinsav-alapú, a genom speciális (elsősorban virulencia) génjeinek kimutatását célzó molekuláris technikák. A rutin élelmiszer-mikrobiológiai vizsgáló laboratóriumok leggyakrabban nemzetközileg validált DNSamplifikációs, elsősorban valós idejü polimeráz láncreakció alapú módszereket alkalmaznak, amelyek a vizsgálati idő jelentős lerövidítése mellett lényegesen javítják a módszerek teljesítési jellemzőit (például érzékenység, specifikusság) is. A polimeráz láncreakció alapú módszereknek rutindiagnosztikai célú alkalmazása azonban az előnyök mellett számos hátránnyal is jár, amelyek között említendő a készülékek és a reagensek magas költsége, valamint a laboratóriumi környezetnek a reakciótermékekkel való kontaminálási kockázata, ami elkülönített laboratóriumi rendszert igényel. Manapság az ilyen laboratóriumi rendszerek miniatürizálása és hordozhatóvá tétele is fontos fejlesztési irány. A Labon-a-chip eszközökben több ilyen laboratóriumi múveletet lehet megvalósítani egy kis méretú eszközön, a standard eljárásokhoz hasonló pontossággal és megbízhatósággal. Ezen miniatürizált eszközök nagy előnye az egyszerü - sokszor automatizált - kezelhetőség, kis méret, hordozhatóság és sterilitás, ami az egyszeri használatból adódik. Ilyen miniatürizált gyorsdiagnosztikai eszközök kutatása és fejlesztése folyik a világ vezető kutatóhelyein, például különbözô minta-előkészítési és DNS-amplifikációs módszerek miniatürizálásával. A szerzők is ezt a célt tűzték ki kutatásaikban: olyan miniatürizált mikrofluidikai eszközök fejlesztését, amelyek alkalmasak élelmiszer-biztonsági jelentőségű baktériumok molekuláris detektálására. Orv. Hetil., 2015, 156(51), 2082-2088.
\end{abstract}

Kulcsszavak: élelmiszer-biztonság, baktériumdiagnosztika, Lab-on-a-chip, mikrofluidikai eszközök

\section{Development of molecular detection of food-borne pathogenic bacteria using miniaturized microfluidic devices}

Detection and identification of food-borne pathogenic bacteria are key points for the assurance of microbiological food safety. Traditional culture-based methods are more and more replaced by or supplemented with nucleic acid based molecular techniques, targeting specific (preferably virulence) genes in the genomes. Internationally validated DNA amplification - most frequently real-time polymerase chain reaction - methods are applied by the food microbiological testing laboratories for routine analysis, which will result not only in shortening the time for results but they also improve the performance characteristics (e.g. sensitivity, specificity) of the methods. Beside numerous advantages of the polymerase chain reaction based techniques for routine microbiological analysis certain drawbacks have to be mentioned, such as the high cost of the equipment and reagents, as well as the risk of contamination of the laboratory environment by the polymerase chain reaction amplicons, which require construction of an isolated laboratory system. Lab-on-a-chip systems can integrate most of these laboratory processes within a miniaturized device that delivers the same specificity and reliability as the standard protocols. The benefits of miniaturized devices are: simple - often automated - use, small overall size, portability, sterility due to single use possibility. These minia- 
turized rapid diagnostic tests are being researched and developed at the best research centers around the globe implementing various sample preparation and molecular DNA amplification methods on-chip. In parallel, the aim of the authors' research is to develop microfluidic Lab-on-a-chip devices for the detection and identification of food-borne pathogenic bacteria.

Keywords: food safety, bacterial diagnostics, Lab-on-a-chip, microfluidic devices

Iván, K., Maráz, A. [Development of molecular detection of food-borne pathogenic bacteria using miniaturized microfluidic devices]. Orv. Hetil., 2015, 156(51), 2082-2088.

(Beérkezett: 2015. október 5.; elfogadva: 2015. október 29.)

\begin{abstract}
Rövidítések
$3 \mathrm{SR}=$ self-sustained sequence replication; IVD = in vitro diag nosztika; LAMP = loop-mediated isothermal amplification; LOC $=$ Lab-on-a-chip (laboratórium egy chipen); NASBA = nucleic acid sequence-based amplification; PCR = polimeráz láncreakció; $\mathrm{RPA}=$ recombinase polymerase amplification; RT-PCR = reverz-transzkriptázos polimeráz láncreakció; SDA $=$ strand displacement amplification
\end{abstract}

A biztonságos élelmiszerek előállítása szempontjából kulcsfontosságú az élelmiszerrel terjedő patogén mikrobák kimutatása és azonosítása. Közülük is első helyen állnak a baktériumok, azonban egyre fontosabbá válik az enteralis vírusok és állati, illetve humán paraziták detektálása is. Az utóbbi 8-10 évben különösen felgyorsult a patogének kimutatására szolgáló diagnosztikumok iránti igény, elsősorban az élelmiszer-gazdaság globalizálódása és az ehhez kapcsolódó élelmiszer-kereskedelem felgyorsulása miatt. Ugyancsak hozzájárult az igények növekedéséhez az élelmiszergyártóknak a biztonságos élelmiszerek előállítására vonatkozó, törvényi szabályozásban is rögzített kötelezettsége és felelössége, valamint az ezek hiányából fakadó felelősségre vonás és kártérítési kötelezettség. A fogyasztók gyors tájékoztatása, az élelmiszerek által kiváltott járványok internetes média általi gyors kommunikálása, valamint a világ különböző országaiban és az EU-ban múködő gyors riasztási rendszerek bevezetése mind-mind hozzájárult az élelmiszer-biztonsági diagnosztika fejlesztése iránti megnövekedett igényekhez, ezen belül is a hagyományos tenyésztéses vizsgálatokat egyszerübbé tevő és lerövidítő gyors módszerek kifejlesztéséhez és elterjedéséhez. A gyors módszereken belül is különleges jelentőségük van a genomvizsgálaton alapuló úgynevezett molekuláris technikáknak, amelyek legfontosabb módszerei a molekuláris hibridizáláson és a DNS-amplifikáción alapszanak.

\section{Az in vitro diagnosztika helye és jelentősége a mikrobiológiai élelmiszer-biztonsági diagnosztikában}

Az in vitro diagnosztika (IVD) olyan tesztek alkalmazását jelenti, amelyeket az emberi szervezet vizsgálatára fejlesztettek ki és célja a kóros múködés, illetve mikrobás fertőzések kimutatása szervezeten kívüli környezetben, általában laboratóriumokban. Az IVD-k lehetnek egyszerû tesztek, de számos esetben magas technikai színvonalon működő, automatizált rendszereket foglalnak magukba, ami lehetôséget teremt nagyszámú minta vizsgálatára, szürésére, valamint a kapott adatok gyors elemzésére és az eredmények tárolására.

Az IVD jelentősége napjainkban az orvosi területen a legnagyobb, és itt rohamos fejlődése figyelhető meg, azonban - mivel az élelmiszer-biztonsági jelentőségü mikroorganizmusok elsősorban az emberi szervezetben okoznak megbetegedést - a mikrobiológiai élelmiszerbiztonsági diagnosztika közvetlenül kapcsolódik az enteralis megbetegedést okozó mikrobák orvosi diagnosztikájához, azzal csaknem teljes mértékben átfedést mutat. Ugyancsak közvetlen kapcsolatban áll az állatorvosi mikrobiológiai diagnosztikával is, mivel az élelmiszerrel terjedő patogének jelentős része zoonotikus, és kimutatásukat eloóriják az emberi fogyasztásra szánt állatok és állati eredetü alapanyagok esetében is.

$\mathrm{Az}$ élelmiszerrel terjedő baktériumok közül a Salmonella enterica szerotípusok, patogén Escherichia coli törzsek, Listeria monocytogenes, Staphylococcus aureus, valamint a különböző Shigella, Vibrio, Chronobacter és Campylobacter fajok kimutatása, esetenként mennyiségi meghatározása áll az első helyen, de egyre inkább megnő az igény az enteralis vírusok (norovírus, rotavírus) és paraziták (protozoonok, peték, ciszták) kimutatására is.

Az IVD-rendszerek egy nagyon gyors fejlődésnek indult ága a Lab-on-a-chip (LOC, laboratórium egy chipen) bioszenzorok. Ezek egyik kiemelkedő típusát képviselik a mikrofluidikai rendszerek, amelyeknek különböző típusai más-más sejtösszetevő kimutatását célozzák. A leggyakrabban alkalmazott diagnosztikai módszerek az immunológiai eljárások és a nukleinsav-amplifikációs technikák, amelyeket a LOC bioszenzorok segítségével miniatürizálni és automatizálni lehet. További előnyük még hordozhatóságuk és egyszerúségük. A LOC-rendszerek sejtszétválogatási és -áramlási citometriás alkalmazásáról olvashatunk Andersson és van den Berg közleményében [1], a sejteket a mikrofluidikai rendszeren belül kezelik és lizálják. A mikrofluidikai rendszerekkel a patogén szenzorok különböző alkalmazásait fejlesztették 
ki. A LOC-rendszerek élelmiszer-biztonsági célú fejlesztésérôl nyújt áttekintést többek között a [2] összefoglaló cikk.

\section{Nukleinsav-amplifikáción alapuló molekuláris módszerek és alkalmazásuk élelmiszerrel terjedő patogének kimutatására}

A DNS-templát molekulák amplifikálásának alapvetően kétféle módszerét fejlesztették ki; ezek közül legnagyobb mértékben a magas denaturációs és amplifikációs hőmérsékletet igénylő polimeráz láncreakció (PCR) terjedt el, míg az alacsonyabb hőmérsékleten múködő amplifikációs módszerek kevésbé ismertek és alkalmazásuk is ritkább. Utóbbiak közé tartozik a NASBA (nucleic acid sequence-based amplification), a 3SR (self-sustained sequence replication), az RPA (recombinase polymerase amplification), az SDA (strand displacement amplification) és a LAMP (loop-mediated isothermal amplification). Ezek közül a hődenaturációt nem igénylő módszerek közül a LAMP [3] rendelkezik a legtöbb előnnyel, ezért főként ezt fejlesztették tovább kutatási és diagnosztikai célra.

\section{A PCR-alapú módszerek jellemzöi és alkalmazási lehetôségei élelmiszer-biztonsági jelentôségü mikrobák kimutatására}

A PCR-reakció során a DNS-t specifikusan, primerek segítségével közvetlenül amplifikálják, vagy pedig a vizsgálandó mintában jelen lévő RNS-ről (általában mRNS-ről vagy vírus-RNS-ről) először reverz transzkriptázzal cDNS-t hoznak létre, amelyet egy következő lépésben a PCR-reakció segítségével amplifikálnak (RT-PCR). A PCR-reakció termékét különböző módszerekkel lehet azonosítani. A hagyományos PCR-reakcióban kimutatása (diagnosztikai szakkifejezéssel a végpontjelzés) agaróz gélelektroforézist követôen DNS-sel interkaláló fluoreszcens vegyülettel (például etidium-bromiddal) való festéssel történik. A várt méretű reakciótermék nukleotidszekvenciájának megerősítése azonban további lépéseket igényel (például RFLP-analízis, hibridizálás, szekvenálás [4]). A PCR-reakció fejlesztésében fordulópontot jelentett a real-time (valós idejü) PCR, amelynek korai szakaszában a reakció során a PCR-termékkel interkaláló festék, a Sybrgreen fluoreszcenciáját folyamatosan detektálták. Ezt követően különböző reakciókkal a PCR-t kvantitatívvá tették (Q-PCR), amelyek közül a PCR-termékhez specifikusan kötődő fluoreszcens próbák (például TaqMan ${ }^{\circledR}$ ) alkalmazása terjedt el legnagyobb mértékben és ennek lett legnagyobb a diagnosztikai jelentősége is [5]. A real-time PCR és az RT-PCR kombinálásával (Q-RT-PCR) a génexpresszió és a vírusrészecskék kvantifikálása $[6,7]$ is lehetôvé vált.

\section{PCR-alapú módszerek alkalmazása élelmiszer- biztonsági jelentöségü mikrobák kimutatására}

A PCR patogén mikrobáknak élelmiszerből való közvetlen detektálására nem alkalmazható, mivel a határértéket jelentő patogén mikroba száma olyan alacsony, hogy kimutatása közvetlenül, az élelmiszerminta vizsgálatával nem lehetséges [8]. Ezért a vizsgálandó minta határértéket jelentő mennyiségében (például $l$ vagy $25 \mathrm{ml}$, illetve gramm) a kimutatandó mikrobát a PCR-reakció előtt dúsító közeg segítségével felszaporítják olyan sejtszámra, amiből már a PCR-es vizsgálathoz megfelelő mennyiségú templát-DNS (vagy RNS) izolálható [9]. Ennek következtében a pozitív PCR-reakció határérték feletti, míg a negatív határérték alatti mikrobaszámot jelez a mintában (úgynevezett jelenlét vagy hiány kimutatása [10]). Jóllehet, a dúsítás 1-2 nappal meghosszabbítja a vizsgálati időt, azonban előnye, hogy a dúsítás során az élelmiszereknél gyakran előforduló PCR-inhibitorok (például egyes lipidek, szénhidrátok, proteázok, tartósítószerek) megfelelően kihígulnak, ezáltal a téves negatív minták aránya csökken. Ugyancsak előnyt jelent, hogy a mintában lévő, esetlegesen elpusztult mikrobákból eredô DNS-molekulák is oly mértékben kihígulnak, ami már a dúsítás utáni mintából izolált DNS-nél nem ad amplifikátumot (téves pozitív eredményt), így a DNSalapú detektálással csak az élő sejtek lesznek kimutathatók.

A real-time PCR-reakciót kiterjedten alkalmazzák élelmiszer-biztonsági mikrobiológiai célra, azonban nem kvantitatív, hanem kvalitatív módszerként, mivel a dúsítási eljárás következtében nem becsülhető meg a mintában lévő célmikroba (baktérium, vírus, protozoon) genomjának kópiaszáma, illetve sejtszáma.

A real-time PCR-nek az egyszerú PCR-rel szemben nagy előnye, hogy az amplifikálás következtében felszaporodó PCR-termék specifikusságát a következő lépésben specifikusan kötődő próba mutatja, ezért a PCR-reakció utáni megerősítő reakcióra (például szekvenálás, hibridizálás) nincs szükség [11].

Az élelmiszerrel terjedő patogén baktériumok kimutatására nagyszámú, elsősorban real-time PCR-es módszert fejlesztettek ki, amelyek közül a kereskedelmi forgalomban lévők többsége nemzetközi szervezet által is validálásra került. Az előzőekben említett valamennyi patogén baktérium kimutatására elérhetők kereskedelmi forgalomban lévő real-time PCR-es tesztek; a legnevesebbek között említhetők az Applied Biosystems, BioRad, DuPont Qualicon, Merck KGaA, Roche Diagnostics és a Sy-Lab.

A real-time PCR-nek az előzőekben említett előnyök mellett számos hátránya is van. Ezek között említendő a készülék és a reagensek magas költsége, valamint az elkülönített laboratóriumi rendszer iránti igény. Ez utóbbit az indokolja, hogy a PCR-reakciót rutindiagnosztikai célra alkalmazó laboratóriumok esetében veszélyt jelent a környezetnek a PCR-termékekkel való kontaminálása, 
ami téves pozitív eredményekhez vezethet, ezért a PCRvizsgáló laboratóriumok felépítésére speciális, szabványokban (például ISO 20838:2006) is rögzített szabályok vonatkoznak [12]. A PCR-reakciónak kontaminációval szembeni érzékenysége miatt különös jelentőségúek a zárt rendszerben megvalósítható vagy az egyszer használatos amplifikációs rendszerek, kitek. A real-time PCR ebból a szempontból is előnyt jelent, mivel nincs szükség a PCR-reakciót követő további vizsgálatra, így lényegesen kisebb a veszélye a PCR-termékkel való kontaminációnak, mint az egyszerú PCR esetében.

\section{A LAMP (loop-mediated isothermal amplification) -módszer és alkalmazása patogén baktériumok kimutatására}

A LAMP-módszer lényege, hogy a DNS amplifikálása nem igényel hődenaturációt a primerek megkötődése elött, a reakciót pedig állandó $\left(60-65^{\circ} \mathrm{C}\right.$ körüli) hőmérsékleten valósítják meg speciális DNS-polimeráz segítségével. Kifejlesztése Notomi és mtsai nevéhez füződik [3], és a japán Eiken Chemical Co. Ltd. (www.eiken.co.jp) szabadalmi oltalommal védi.

A módszer lényege, hogy 4 különböző primer a célDNS-en 6 különböző helyet ismer fel és ezek indítják el a reakciót. Számos esetben még további kettő, 4 másik helyet felismerô primert is alkalmaznak, amelyek a specifikusságot tovább növelik. A reakció eredményeként különböző méretű hajtűhurkok és több hurkot tartalmazó karfiolszerú struktúrák jönnek létre. A cél-DNS 15-60 perc alatt $10^{9}-10^{10}$-szeresére felszaporodik. A reakció előrehaladtával a melléktermékként keletkező magnézium-pirofoszfát koncentrációja oly mértékben megnő, hogy az a reakcióközeg turbiditásának szemmel látható és turbidiméterrel mérhetố növekedéséhez vezet. A detektálás nemcsak turbiditás révén, hanem színváltozás alapján vagy fluoreszcenciás és kemilumineszcenciás végpontjelzéssel is megvalósítható. A LAMP nemcsak érzékenyebb és specifikusabb, mint a PCR-reakció, hanem robusztusabb is, továbbá a biológiai anyagokban és élelmiszerekben gyakran jelen lévő inhibitorokra kevésbé érzékeny, mint a PCR.

A LAMP-módszer alkalmazásával jóval kevesebb IVDkészüléket fejlesztettek ki élelmiszer-eredetû patogén baktériumok kimutatására, mint a real-time PCR esetében. Ezek közül egyik az Eiken Loopamp Realtime Turbidimeter (LA-500), a másik pedig a 3M (www.3M. com) kemilumineszcenciás detektálással múködő Molecular Detection System készüléke. Mindkettóvel megvalósítható a Salmonella, patogén E. coli törzsek és Listeria monocytogenes kimutatása, az Eiken cég pedig ezeken kívül a termofil Campylobacter fajok kimutatására is fejlesztett ki tesztet.

A LAMP-módszer a patogének detektálásán kívül számos egyéb területen is alkalmazást nyert, mint például a GMO-detektálás, tumordetektálás és az embrió nemének meghatározása [13].

\section{Mikrofluidikai rendszerben megvalósítható eljárások}

\section{A mikrofluidika és a komplex miniatürizált eszközökben rejlo" lehetöségek}

A laboratórium egy chipen (LOC) eszközök fejlesztése egy multidiszciplináris feladat a mérnöki tervezés, a fizika, a kémia, a mikrotechnológia és a biotechnológia határán. Ennek fontos eleme a mikrofluidika, amely a folyadékok viselkedésével, precíz irányításával és manipulációjával foglalkozó terület. A kis mérettartomány miatt szükség van ezzel külön foglalkozni, hiszen a folyadék mennyisége a mikroliteres és nanoliteres tartományba esik, a csatornák mérete a készülékben milliméter alatti, tehát a mikroméretû viselkedés a meghatározó a rendszerben. A hétköznapi életben megszokott jelenségektől kissé eltérnek a mikroméretekben tapasztalt folyamatok, például a keveredés nem olyan egyértelmúen jön létre két folyadék között. Továbbá az energiafogyasztás és a készülékek alacsony ára (akár $300 \mathrm{Ft}$-os nagyságrend) is vonzó lehet ennek a témának a vizsgálatához.

Egy tipikus mikrofluidikai eszköz alapja több különböző alapegység, amelyek közösen végeznek el egy öszszetettebb feladatot. Ezek az alapegységek például keverők, elválasztók, reakcióterek vagy csak egyszerú csatornák, amelyekben a folyadék áramlik. Ezek az úgynevezett passzív elemek. Vannak aktív elemek is (például fútő, ultrahangos egység, elektródok), amelyek hozzáadásával további funkciókat adhatunk a készüléknek. A folyadék mozgatása pumpák és szelepek segítségével jöhet létre, amelyek többnyire nincsenek az eszközbe integrálva, de léteznek olyan rendszerek, amelyekben beépített szivattyúk vagy hasonló mechanizmusok találhatók [14]. A mikrofluidikai eszközök fejlesztése az 1980-as években kezdődött, de ezen technológia valódi térnyerése az elmúlt 15 évben történt. Ez azért van, mert új anyagok (fóleg polimerek) lehetővé tették az egyre olcsóbb gyártást, valamint ezekkel sikerült elérni a mikrotechnológiai pontosságot és megbízhatóságot. Ezen eszközök egyik legnagyobb elónye nemcsak az árúk, hanem a hordozhatóság, a gyorsaság, a pontosság és az automatizálhatóság is. Ezek a tulajdonságok abból adódnak, hogy a reagensek térfogata és a csatornageometriák jóval kisebbek, mint a hagyományos eszközökben. Emiatt gyorsabban lezajlanak a reakciók, hasonló eredménnyel és pontossággal, mint a hagyományos eszközökben, amelyek mintamennyisége és geometriai mérete makroméretű. Mivel a mikrofluidikai eszközök mérete kicsi (néhány centiméter), emiatt hordozhatók is lehetnek. A nagy komplexitás miatt az automatizálási módszerek is könnyen alkalmazhatók, aminek segítségével könnyebb az eszközök használata. Ennek segítségével a fogyasztói piac megfelelő része célozható meg, mert nincs szükség jól képzett szakemberre a használatához (lásd például a terhességi vagy vércukorszintméró tesztcsíkok elterjedtségét). Ezekkel az előnyökkel jár 
azonban az a nehézség, hogy a mikronos mérettartományban, bár a fizikai törvények ugyanazok, de a megfigyelhető jelenségek és a viselkedés eltérő a hétköznap megszokottól.

\section{Mikrofluidikai eszközökben megvalósitott nukleinsav-alapú módszerek}

A mikrofluidika terjedésével a biológiai alkalmazások - mint például nukleinsav-alapú tesztek - egyre népszerúbbek [15]. Az e mögött álló motiváció egyrészt a Humán Genom Projekt, valamint a hatalmas piaci lehetőségek voltak. Az ilyen típusú vizsgálatokkal és elemzésekkel a DNS-ben kódolt információ nagy része ismertté vált. Az eszközök segítségével lehetőség nyílt vizsgálatokra a betegségek korai szakaszában, fokozott kockázati tényezők vizsgálatára, valamint a genetikailag öröklött betegségek feltérképezésére.

A legtöbb DNS-alapú vizsgálatban a PCR egy kulcsfontosságú lépés, ezért ennek az integrációja a mikrofluidika-rendszerekbe volt az egyik legfontosabb feladat. A probléma megoldására számos mikrofluidikai eszköz jött létre a közelmúltban. Folyamatos áramlású PCR-t hoztak létre üvegeszközben [16]. Ez a chip egy olyan csatornából áll, amely két régió felett hurokban van kialakítva. Mindkettő egy integrált indium-ón-oxid réteggel fütött felszín, amelyek a megfelelő hőmérsékletért felelösek.

A PCR-t összekapcsolva más folyamatokkal, egy komplexebb rendszert is ki lehet alakítani [17]. A megoldás egy olyan eszköz, amely képes a sejtek elkülönítésére és a PCR-amplifikációs feladat megvalósítására. Az izolációt egy gát típusú szứrővel érték el. Múködési elve a résszúroón alapul, ahol kis réseket kialakítva a sejtek nem tudnak azokon átjutni. Bár úgy hangzik, mint egy egyszerü és hatékony elválasztási módszer, számos probléma fordulhat elő múködése során (rések elzáródása, sejtek átpréselődése). A szürő́n való átáramoltatás után az oldat eléri a második modult, amely tartalmazza a fútési és hútési modulokat. Ebben a modulban létrejön a PCR az elókészített mintán. Egy komplex chip került bemutatásra 2000-ben [18]. Ebben nyolc PCR végezhető el párhuzamosan, valamint kapilláris elektroforézis $(\mathrm{CE})$ is. A mikrofluidikai csatornákat üvegben alakították ki és a fútőszálakat is ennek a felületére rögzítették. A PCR-reakció gyorsan végbement a reakciótérben (30 másodperc alatt egy teljes ciklus). Ez után a mintát átpumpálták a CE-alapú elválasztócsatornába, amely előre ki volt töltve a megfelelő elválasztáshoz szükséges közeggel. Egy hasonló eszközt hoztak létre a Peltier-típusú termoelem segítségével [19]. Ennek az eszköznek az előnye, hogy a fütést és a hútést is ugyanazon elem végzi. A kísérletek szerint a chip képes volt elvégezni egy PCR-ciklust percenként. Vannak olyan kutatási irányok, ahol a gyors PCR-technológiát különböző anyagokban valósítják meg. Az egyik példa a poli(metil-)metakrilát (PMMA) eszközben bemutatott eredmény [20]. Az eszköz a
DNS-elemzéshez PCR-t és párhuzamosan kapilláris elektroforézist is alkalmaz. E mikrofluidikai eszközök népszerúségét is tökéletesen mutatja az a tény, hogy már a kereskedelemben is kaphatók (például Agilent), valamint több kutatócsoport is használja ezeket [21, 22] kísérleti alaprendszernek.

A chipen végzett PCR-t gyakran kombinálják más folyamatokkal, mint például DNS-hibridizációval [23]. Egy polikarbonát alapú chipet és Peltier-elemeket alkalmaztak a hőmérséklet-szabályozáshoz. A folyadékáramoltatást külső fecskendôpumpákkal és beépített szelepekkel valósították meg. Több sikeres DNS-hibridizációt is demonstráltak a chipen. Polikarbonát alapú chipeket is használnak a HIV-genom feltérképezéséhez [24], valamint üvegalapú eszközökben is ki lehet alakítani a DNShibridizációs vizsgálatokat [25].

A fentiekben néhány mikrofluidikai alapú PCR-rendszert mutattunk be. Bár ezek a rendszerek nagyon jó és kifejlett konstrukciók, közös problémájuk lehet a hőmérséklet ciklikus változtatása. A PCR-hez hasonló például izoterm erősítési módszerek alkalmazása itt is lehetséges. Ezek közül az egyik a már említett RPA. Ez a módszer tulajdonságai miatt jobban illik a miniatürizációs alkalmazásokhoz. Nem kellenek különböző hőmérsékletű régiók, és hosszabb DNS-szekvencia amplifikációját is végre tudja hajtani rövidebb időn belül, mint a hagyományos PCR. Az egyik RPA-alapú mikrofluidikai eszköz [26] jó példa arra, hogy milyen mértékű komplexitást lehet mikrofluidikai eszközzel elérni. Egy ilyen eszköz képes arra, hogy egy teljes nukleinsav-amplifikációs eljárást elvégezzen. A másik ilyen izoterm módszer a LAMP. Ez is jól megvalósítható mikrofluidikai eszközökben, mert izoterm és jobban teljesít, mint a hagyományos PCR. Több ilyen eszközt is publikáltak már [27].

\section{Javaslatunk a miniatürizált, élelmiszer-mikrobiológiai vizsgálatot elvégző mikrofluidikai rendszerre}

Projektünk célja, hogy hasonló eszközt hozzunk létre feladatspecifikusan; nevezetesen, míg a publikált készülékek elsősorban orvosi diagnózishoz készültek, terveinkben a mikrobiológiai élelmiszer-biztonsági feladatokra fókuszálunk.

Egy önálló diagnosztikai eszköz egyik legfontosabb kritériuma az, hogy minél gyorsabban szolgáltasson eredményt a minta bejuttatásától egy integrált és gyors analizálórendszer segítségével különböző vizsgálandó minták esetén. Ez a minta lehet mikroorganizmus - például vírus, baktérium - vagy emberi sejt - például vérsejt vagy szöveti sejt-, illetve élelmiszerminta. A különböző típusú minták DNS-amplifikációra való elókészítése nagy kihívást jelent, mivel a diagnózis meglehetősen eltérő lehet. Az elsô lépés egy ilyen diagnosztikai platform esetén a mintafeldolgozó egység fejlesztése, amely képes kinyerni a nukleinsavat az adott mintából. Számos meglé- 
vő lehetőség van az ilyen jellegű előkészítésre folyékony vagy szilárd minták esetén is. A minta-előkészítés utáni következő lépés az, hogy az extrahált nukleinsavat egy detektálható mennyiséggé amplifikáljuk; és végül az amplifikált terméket kimutassuk. A készülék mikrofluidikai környezetben való megvalósítása számos előnnyel jár, például a kis mintatérfogat (5-40 mikroliter), gyorsabb vizsgálati folyamat, alacsonyabb költségek, a hordozhatóság és sterilitás az egyszeri használatból adódóan.

$\mathrm{Az}$ irodalmi áttekintés alapján a mikrofluidikai alapú LOC-rendszerek alkalmazása és továbbfejlesztése élelmiszerrel terjedő patogén baktériumok kimutatására nukleinsav- (elsősorban DNS-) alapon ígéretes. Ehhez leginkább a LAMP izotermiás amplifikációs eljárás látszik megfelelőnek, mivel nem igényel hődenaturációt, és jóval érzékenyebb, mint a hagyományos, illetve real-time PCR. Mivel az élelmiszerekből történő patogénkimutatást meg kell, hogy előzze egy dúsítási lépés, amelynek során a mintában lévő, esetlegesen elpusztult mikrobákból eredő DNS-molekulák oly mértékben kihígulnak, ami már a dúsítás utáni mintából izolált DNS-nél nem ad amplifikátumot, ezért a DNS-alapú detektálással csak az élő sejtek lesznek kimutathatók.

A minta előkészítéséhez és feldolgozásához, a keveréshez egy passzív, geometriaalapú módszert tervezünk alkalmazni, hogy a költségeket hatékonyan alacsonyan tudjuk tartani a külső erőforrások eliminálása révén. Ez motiválja a folyadékmozgatási módszert is, ahol a vákuumalapú beszívási technikát tervezzük implementálni. Ezzel számos jó tulajdonságot tudunk az eszköznek kölcsönözni. Hatásos folyadékszívási energiát tartalékolva a rendszerben, csökkenteni tudjuk a költségeket, valamint megfelelő csomagolással könnyen kezelhetővé, automatikussá és felhasználóbaráttá tehető az eszköz. A fütőrendszer biztosítja a szükséges hőmérsékletet az amplifikációhoz és a technológiát az amplifikáció eredményének kimutatására. A módszer kis mennyiségû mintát igényel, csak egy hőmérséklet szükséges az erősítéshez és vizsgálathoz, a keveréket bejuttatjuk a bemeneten és egy gyors reakció után az eredmény könnyen kimutatható.

Az eszközt bármikor aktiválni tudjuk, a LAMP-eredmények könnyen kiolvashatók a zavarosság kialakulása következtében, de a mérettartomány miatt szükségünk van egy integrált detektorra is, optikai szálra az eszközön belül az érzékeny és pontos eredmények érdekében. Az optikai szálak segítségével könnyen mérhetjük az optikai szórás mértékét, ami a költségigényt is minimális szinten tudja tartani.

Sok vírus, baktérium vagy más mikroorganizmus okozta fertőzés van világszerte, de elterjedt gyorstesztek még nem léteznek ezek kimutatására. A vizsgálatokhoz szükség van könnyen használható diagnosztikai eszközökre, amelyek megfizethetőek és jó minőségúek: olcsó, gyors diagnózisra képes, nincs szükség hozzá szakemberre, valamint hordozható és könnyen használható az adott eszköz.
Anyagi támogatás: A közlemény megírása anyagi támogatásban nem részesült.

Szerzôi munkamegosztás: A szerzők egyenlő mértékben járultak hozzá a közlemény elkészítéséhez. A cikk végleges változatát mindkét szerző elolvasta és jóváhagyta.

Érdekeltségek: A szerzőknek nincsenek érdekeltségeik.

\section{Irodalom}

[1] Andersson, H., van den Berg, A.: Microfluidic devices for cellomics: a review. Sensors Actuators B: Chemical, 2003, 92(3), 315-325.

[2] Yoon, J. Y., Kim, B.: Lab-on-a-chip pathogen sensors for food safety. Sensors, 2012, 12(8), 10713-10741.

[3] Notomi, T., Okayama, H., Masubuchi, H., et al.: Loop-mediated isothermal amplification of DNA. Nucleic Acids Res., 2000, $28(12)$, e63.

[4] Bermingham, N., Luettich, K.: Polymerase chain reaction and its applications. Current Diagn. Pathol., 2003, 9(3), 159-164.

[5] Deepak, S., Kottapalli, K., Rakwal, R., et al.: Real-time PCR: revolutionizing detection and expression analysis of genes. Curr. Genomics, 2007, 8(4), 234-251.

[6] Nolan, T., Hands, R. E., Bustin, S. A.: Quantification of mRNA using real-time RT-PCR. Nat. Protoc., 2006, 1(3), 1559-1582.

[7] Lien, K. ., Lee, W. C., Lei, H. ., et al.: Integrated reverse tran scription polymerase chain reaction systems for virus detection. Biosens. Bioelectron., 2007, 22(8), 1739-1748.

[8] Maraz, A., Marin, F., Cava, R.: Microbial control of food. In: Luning, P. A., Devlieghere, F., Verhé, R. (eds.): Safety in the agri-food chain. Wageningen Academic Pub., Wageningen, 2006.

[9] Justé, A., Thomma, B. P., Lievens, B.: Recent advances in molecular techniques to study microbial communities in food-associated matrices and processes. Food Microbiol., 2008, 25(6), 745-761.

[10] Hill, W., Jinneman, K.: Principles and application of genetic techniques for detection, identification and subtyping of foodassociated pathogenic microorganisms. In: Lund, B. M., BairdParker, T. C., Gould, G. W. (eds.): The microbiological safety and quality of food. Aspen Publishers, Maryland, 2000, Vol. 2, 1813-1851.

[11] McKillip, J. L., Drake, M.: Real-time nucleic acid-based detection methods for pathogenic bacteria in food. J. Food Prot., 2004, 67(4), 823-832.

[12] Malorny, B., Tassios, P. T., Rådström, P., et al.: Standardization of diagnostic PCR for the detection of foodborne pathogens. Int. J. Food Microbiol., 2003, 83(1), 39-48.

[13] Fu, S., Qu, G., Guo, S., et al.: Applications of loop-mediated isothermal DNA amplification. Appl. Biochem. Biotechnol., 2011, 163(7), 845-850.

[14] Dimov, I. K., Basabe-Desmonts, L., Garcia-Cordero, J. L., et al.: Stand-alone self-powered integrated microfluidic blood analysis system (SIMBAS). Lab Chip, 2011, 11(5), 845-850.

[15] Erickson, D., Li, D.: Integrated microfluidic devices. Anal. Chim. Acta, 2004, 507(1), 11-26.

[16] Sun, K., Yamaguchi, A., Ishida, Y., et al.: A heater-integrated transparent microchannel chip for continuous-flow PCR. Sensors Actuators B: Chemical, 2002, 84(2-3), 283-289.

[17] Yuen, P. K., Kricka, L. J., Fortina, P., et al.: Microchip module for blood sample preparation and nucleic acid amplification reactions. Genome Res., 2001, 11(3), 405-412.

[18] Lagally, E. T., Simpson, P. C., Mathies, R. A.: Monolithic integrated microfluidic DNA amplification and capillary electrophoresis analysis system. Sensors Actuators B: Chemical, 2000, $63(3), 138-146$ 
[19] Khandurina, J., McKnight, T. E., Jacobson, S. C., et al.: Integrated system for rapid PCR-based DNA analysis in microfluidic devices. Anal. Chem., 2000, 72(13), 2995-3000.

[20] Ueda, M., Nakanishi, H., Tabata, O., et al.: Imaging of a band for DNA fragment migrating in microchannel on integrated microchip. Materials Sci. Engin. C, 2000, 12(1), 33-36.

[21] McCaman, M. T., Murakami, P., Pungor, E. Jr., et al.: Analysis of recombinant adenoviruses using an integrated microfluidic chipbased system. Anal. Biochem., 2001, 291(2), 262-268.

[22] Sobni, Y. R., Burke, J. P., Dyck, P. J., et al.: Microfluidic chipbased method for genotyping microsatellites, VNTRs and insertion/deletion polymorphisms. Clin. Biochem., 2003, 36(1), $35-40$.

[23] Liu, Y., Rauch, C. B., Stevens, R. L., et al.: DNA amplification and hybridization assays in integrated plastic monolithic devices. Anal. Chem., 2002, 74(13), 3063-3070.
[24] Anderson, R. C., Su, X., Bogdan, G. J., et al.: A miniature integrated device for automated multistep genetic assays. Nucl. Acids Res., 2000, 28(12), e60.

[25] Fan, Z. H., Mangru, S., Granzow, R., et al.: Dynamic DNA hybridization on a chip using paramagnetic beads. Anal. Chem., 1999, $71(21), 4851-4859$.

[26] Hakenberg, S., Hïgle, M., Weidmann, M., et al:: A phaseguided passive batch microfluidic mixing chamber for isothermal amplification. Lab Chip, 2012, 12(21), 4576-4580.

[27] Myers, F. B., Henrikson, R. H., Bone, J., et al.: A handheld pointof-care genomic diagnostic system. PloS ONE, 2013, 8(8), e70266.

(Maráz Anna dr., Budapest, Somlói út 14-16., 1118 e-mail: anna.maraz@uni-corvinus.hu)

\section{A rendezvények és kongresszusok híranyagának leadása}

a lap megjelenése előtt legalább 40 nappal lehetséges, a 6 hetes nyomdai átfutás miatt. Kérjük megrendelőink szíves megértését.

A híranyagokat a következő címre kérjük:

Orvosi Hetilap titkársága: Budai.Edit@akkrt.hu

\section{Akadémiai Kiadó Zrt.}

